\title{
Persepsi Wisatawan Terhadap Objek Daya Tarik Wisata Tenganan Pegringsingan, Kabupaten Karangasem
}

\author{
Ni Luh Apriani*1, Naswan Suharsono², Lulup Endah Tripalupi ${ }^{3}$ \\ Program Studi Pendidikan Ekonomi \\ Universitas Pendidikan Ganesha \\ Singaraja, Indonesia
}

\begin{abstract}
e-mail: niluh.apriani1997@gmail.com*1,naswan.suharsono@undiksha.ac.id², tripalupilulup@gmail.com³
\end{abstract}

Riwayat Artikel

Tanggal diajukan:

8 Januari 2020

Tanggal diterima : 4 Juni 2020

Tanggal dipublikasikan: 29 Juni 2020
Pengutipan:

Apriani, N. L.

Suharsono, N. \&

Tripalupi, L. E.

(2020). Persepsi

Wisatawan

Terhadap Objek

Daya Tarik

Wisata Tenganan

Pegringsingan,

Kabupaten

Karangasem.

Jurnal Pendidikan

Ekonomi

Undiksha, 12 (1)

97-106

\section{Abstrak}

Tujuan penelitian ini adalah mengetahui persepsi wisatawan terhadap objek daya tarik wisata Tenganan Pegringsingan. Jenis penelitian ini termasuk penelitian deskriptif kualitatif. Populasinya adalah wisatawan yang berkunjung ke Tenganan Pegringsingan yang berjumlah tidak terhingga dan sampel diambil sebanyak 100 responden dengan teknik incidental sampling. Data dikumpulkan menggunakan kuesioner dan dianalisis dengan teknik analisis deskriptif. Hasil penelitian menunjukkan bahwa persepsi wisatawan terhadap daya tarik wisata Tenganan Pegringsingan ditinjau dari dimensi attractions, amenities dan accessibility yaitu sangat setuju. Hal tersebut berarti objek wisata Tenganan Pegringsingan memiliki keunikan alam, tradisi dan budaya. Adanya wisata tracking, masyarakat yang ramah, lingkungan objek wisata yang aman, tidak dipungut biaya masuk (adanya donasi yang dapat menyumbang secara sukarela), tersedia sarana pendukung dan memiliki kemudahan akses menuju daya tarik wisata Tenganan Pegringsingan.

Kata kunci: daya tarik wisata; Tenganan Pegringsingan; wisatawan

\begin{abstract}
The purpose of this study was to determine the tourist's perceptions about Tenganan Pegringsingan tourist attraction. This type of research is a qualitative descriptive study. The population of the study is tourists visiting Tenganan Pegringsingan with an infinite number and 100 respondents were taken using incidental sampling techniques. Data were collected using a questionnaire and analyzed with descriptive analysis techniques. The results showed that tourists' perceptions of Tenganan Pegringsingan tourist attraction in terms of the dimensions of attractions, amenities and accessibility were very amenable. That means Tenganan Pegringsingan tourist attraction has a unique nature, tradition and culture. The existence of a tracking tour, a friendly community, a safe tourist attraction environment, no entrance fee (there are donations that can contribute voluntarily), supporting facilities are available and have an easy access to Tenganan Pegringsingan tourist attraction.
\end{abstract}

Keywords: tourist attraction; tenganan pegringsingan, tourists 


\section{PENDAHULUAN}

Objek wisata yaitu suatu tempat wisata yang dijadikan sebagai daya tarik bagi wisatawan sehingga akan menimbulkan perasaan yang senang dan puas ketika mengunjungi destinasi wisata tertentu (Wardiyanta, 2010). Keberadaan objek wisata menjadi sesuatu yang penting dalam kegiatan wisata, hal tersebut karena wisatawan akan mengunjungi daerah tujuan wisata apabila memiliki potensi sebagai tempat wisata (Devy, 2017).

Tenganan Pegringsingan sebagai objek wisata yang sangat menarik untuk dijadikan tujuan kunjungan wisata. Objek daya tarik wisata Tenganan Pegringsingan merupakan destinasi wisata di Kabupaten Karangasem. Objek wisata ini memiliki beragam daya tarik yang dapat menjadi hal menarik bagi wisatawan. Beragam daya tarik wisata tersebut yaitu memiliki keindahan alam, perbukitan, persawahan, perumahan dan bangunan penduduk yang tradisional, adanya wisata tracking, adanya beragam souvenir yang unik berupa kerajinan dan karya seni, adanya beragam tradisi dan budaya yang dilaksanakan dan dapat disaksikan secara langsung oleh wisatawan. Berbagai komponen atau produk wisata yang disediakan tersebut menjadi daya tarik untuk objek wisata Tenganan Pegringsingan.

Banyaknya daya tarik wisata yang disediakan seharusnya dapat mendorong kedatangan wisatawan. Namun jumlah kunjungan wisatawan pada objek wisata Tenganan Pegringsingan mengalami penurunan jumlah kunjungan. Data kunjungan wisatawan objek wisata Tenganan Pegringsingan pada tahun 2014 2018 menurut data kunjungan Kantor Desa Tenganan sebagai berikut.

Tabel 1. Data kunjungan wisatawan

\begin{tabular}{cc}
\hline Tahun & Jumlah \\
\hline 2014 & 44.109 orang \\
2015 & 41.962 orang \\
2016 & 47.119 orang \\
2017 & 32.262 orang \\
2018 & 28.469 orang \\
\hline
\end{tabular}

(Sumber: data kunjungan wisatawan dari kantor desa Tenganan, 2019)
Dari data tersebut menunjukkan objek wisata Tenganan Pegringsingan mengalami penurunan jumlah kunjungan wisatawan. Jumlah kunjungan tahun 2015 mengalami penurunan sebesar 2.147 orang dari tahun kunjungan wisatawan tahun 2014. Pada tahun 2016 jumlah kunjungannya meningkat yaitu sebesar 5.157 orang dari tahun 2015. Namun di tahun 2017 jumlah kedatangan wisatawan menurun sekitar 14.857 orang dari tahun 2016. Sedangkan pada tahun 2018 jumlah kunjungannya menurut sebesar sekitar 3.793 orang dari tahun 2017. Objek wisata Tenganan Pegringsingan merupakan objek wisata yang sudah lama sebagai tempat wisata budaya. Namun masih mengalami penurunan kunjungan wisatawan yang cukup tinggi. Menurut Yudiana selaku kepala Desa Tenganan tahun 2019, "penurunan jumlah kunjungan wisatawan yang tinggi pada tahun 2017 dan 2018 disebabkan oleh faktor alam yaitu adanya isu bahwa Gunung Agung di Kabupaten Karangasem berada di level siaga (diperkirakan akan meletus)".

Berbagai upaya yang dilakukan pengelola objek wisata, guna untuk meningkatkan kunjungan wisatawan dan mengembangkan objek wisata Tenganan Pegringsingan. Pengelola objek wisata Tenganan Pegringsingan terus melakukan inovasi dan pengembangan guna dapat menarik wisatawan. Pengelola Objek wisata Tenganan Pegringsingan berusaha memberikan kelengkapan fasilitas seperti adanya toilet yang dibangun pada tahun 2012, tempat parkir yang sebelah timur dibangun pada tahun 2015, warung makan dan minum dan adanya toko souvenir yang terdapat di area parkir dibangun pada tahun 2015

Penurunan jumlah kunjungan wisatawan ke objek wisata dapat disebabkan oleh beberapa faktor yaitu kondisi objek wisata, kebijakan yang ditetapkan pada objek wisata dan kualitas sumber daya manusia untuk menerima kedatangan wisatawan (Nugroho, 2016). Selain itu penurunan kunjungan wisatawan juga dapat disebabkan kurangnya melibatkan penduduk sekitar, pihak pengelola tidak melibatkan masyarakat dalam mengembangkan objek wisata dan 
masih minimnya promosi yang dilakukan untuk objek wisata (Wilopo \& Hakim, 2017). Penurunan disebabkan karena wisatawan tidak mendapatkan kenyamanan dan kesenangan selama mengunjungi suatu objek wisata. Wisatawan dalam melakukan kunjungan ke suatu daerah wisata memiliki beragam motif yaitu untuk merasakan suasana yang berbeda, melaksanakan sesuatu yang baru, untuk menciptakan ketenangan dan perasaan santai dalam fikiran (Witarsana, 2017).

Elemen utama jalannya kegiatan pariwisata pada daerah tujuan wisata ditandai dengan adanya kunjungan wisatawan ke objek wisata. Wisatawan dapat diartikan sebagai seseorang atau sekelompok orang yang melaksanakan kunjungan wisata untuk sementara waktu atau kurang dari dua puluh empat jam (Fajri \& Riyanto, 2016). Senada dengan pendapat Suarnayasa (2019) yang menyatakan wisatawan adalah seseorang yang sedang melakukan perjalanan ke daerah tujuan wisata dalam periode waktu tertentu. Wisatawan ketika akan melakukan kunjungan wisata pada suatu objek wisata apabila terdapat faktor yang menjadi motivasi wisatawan untuk melakukan kunjungan tersebut. Keberhasilan suatu objek wisata tergantung dari komponen atau produk wisata yang ditawarkan kepada wisatawan.

Menurut Utama (2017) objek daya tarik wisata terdiri dari objek wisata alam, objek wisata budaya, dan objek wisata buatan. Menurut Holloway (2009) keberhasilan dalam menarik wisatawan tergantung pada tiga komponen penting yang ditawarkan objek wisata kepada wisatawan yaitu attractions, amenities dan accessibility. Attractions/ atraksi adalah segala hal yang menarik pada objek wisata sehingga wisatawan tertarik untuk berkunjung ke objek wisata tersebut. Wisatawan mengunjungi daerah wisata untuk memperoleh hal-hal yang tidak temukan pada kehidupan mereka seharihari. Suatu tempat wisata akan disebut objek wisata apabila memiliki beragam atraksi yang mampu memikat wisatawan untuk pergi berkunjung ke daerah tujuan kunjungan wisata (Nisa \& Abrani, 2014).
Amenities/ fasilitas adalah layanan penting yang digunakan untuk memenuhi kebutuhan wisatawan pada objek wisata sehingga membuat wisatawan merasa nyaman berada pada daerah tujuan wisata tersebut. Kondisi suatu fasilitas perlu diperhatikan oleh pihak pengelola industri wisata, pengujung akan merasa senang jika ada fasilitas yang dirawat dengan baik (Anggraeni, 2013).

Sedangkan accessibilityl akses adalah kemudahan bagi wisatawan dalam mencapai daerah tujuan wisata yang akan dikunjungi. Pada suatu objek wisata sangat penting untuk menyediakan akses jalan yang mudah, agar wisatawan dapat menjangkau objek wisata tersebut. Adanya suatu aksesibilitas pada objek wisata dapat memberikan kemudahan bagi wisatawan untuk menjangkau suatu objek (Abdulhaji \& Ibnu, 2016). Dalam destinasi wisata adat elemen yang saling mendukung dan saling berkaitan sehingga terbentuknya daya tarik wisata yang mempesona bagi wisatawan (Sayangbatti \& Baiquni, 2013). Keputusan wisatawan dalam berkunjung ke objek wisata didasarkan atas komponen/produk wisata yang ditawarkan (Abdullah \& Firdaus, 2017).

Suatu objek wisata dapat berkembang dan dijadikan sebagai daerah tujuan wisata oleh wisatawan tergantung dari persepsi atau penilaian wisatawan yang diberikan untuk objek wisata. Persepsi adalah suatu pendapat atau kesan tentang pengalaman yang dikemukakan individu terhadap suatu objek yang menjadi stimulasi yang ditangkap dengan menggunakan panca indera. Pengalaman yang pernah dialaminya dapat dijadikan acuan dalam mempersepsikan sesuatu. Menurut Rakhmat (2013) menyatakan persepsi merupakan seseorang yang melakukan pengamatan baik pada objek, peristiwa/hubungan yang diakhiri dengan adanya penyimpulan dan penafsiran. Dari pengamatan tersebut oleh individu, individu akan memperoleh dan memiliki pengalaman terhadap objek, dari pengalaman tersebut individu memberikan kesimpulan dan penafsiran dari pengamatan objek yang dilakukan.

Dalam kaitanya dengan pariwisata persepsi wisatawan terhadap objek wisata 
dapat berupa persepsi positif dan negatif. Di dunia pariwisata persepsi dimaksud suatu pandangan yang dilakukan oleh penikmat wisata dalam memahami suatu destinasi wisata (Fentri 2017). Semakin mendapat persepsi yang baik dari wisatawan akan produk wisata yang tersedia, maka akan dapat menarik wisatawan untuk datang ke objek wisata (Anggela \& Sofia, 2017). Persepsi wisatawan terhadap daerah tujuan wisata akan berpengaruh kepada image objek wisata, promosi dan sebagai sumber informasi bagi wisatawan baru, yang akan mengunjungi daerah tujuan wisata yang sama (Suwena \& Widyatama, 2017). Kondisi objek akan mempengaruhi perilaku individu atau calon wisatawan dalam melakukan suatu penilaian terhadap lingkungannya. Semakin baik produkproduk wisata yang disediakan oleh daerah wisata, maka akan banyak wisatawan yang akan berkunjung.

Dalam rangka mengembangkan objek daya tarik wisata Tenganan Pegringsingan kepada wisatawan guna dapat meningatkan jumlah kunjungan wisatawan. Penting bagi peneliti mengetahui persepsi wisatawan terhadap objek daya tarik wisata Tenganan Pegringsingan, Kabupaten Karangasem. Penelitian ini bertujuan untuk mengetahui persepsi wisatawan terhadap objek daya tarik wisata Tenganan Pegringsingan terkait dimensi attractions, amenities dan accesabilty

\section{METODE}

Jenis penelitian yang digunakan dalam penelitian ini adalah penelitian deskriptif dengan pendekatan kualitatif. Menurut Noor (2011) penelitian deskriptif ialah penelitian yang dilakukan dengan menjabarkan suatu gejala, peristiwa, kejadian yang terjadi pada saat sekarang. Penelitian ini dilakukan untuk mendeskripsikan mengenai persepsi wisatawan terhadap objek daya tarik wisata Tenganan Pegringsingan, Kabupaten Karangasem yang ditinjau dari dimensi attractions, amenities dan accessibility. Penelitian yang berlokasi di Desa Tenganan, Kecamatan Manggis, Kabupten Karangasem pada objek wisata Tenganan Pegringsingan. Populasi yang dipergunakan oleh peneliti adalah wisatawan yang berkunjung ke objek daya tarik wisata
Tenganan Pegringsingan. Dengan teknik pengambilan sampel Insidental sampling. Dasar penentuan sampel menggunakan Insidental sampling karena jumlah populasi kunjungan wisatawan tidak diketahui secara pasti. Sehingga dalam penentuan sampel menggunakan rumus Purba (dalam sujarweni, 2015) sebagai berikut.

$$
n=\frac{z^{2}}{4(m o e)^{2}}
$$

dimana:

$\mathrm{n}$ adalah jumlah sampel, $\mathrm{Z}$ adalah tingkat distribusi normal pada tarif signifikan 5\% yaitu 1,96 dan Moe adalah Margin of Error Max, yaitu tingkat kesalahan maksimal pengambilan sampel yang masih dapat ditoleransi atau yang diinginkan. Apabila diaplikasikan dengan menggunakan margin of error max sebesar $10 \%$ dan tingkat keyakinan sebesar $95 \%$ atau 1.96, maka jumlah sampel dapat diambil sebanyak 100 orang wisatawan.

Jenis data dalam penelitian ini yaitu data kualitatif dengan sumber data yaitu data primer. Metode pengumpulan data yaitu kuesioner dengan menggunakan skala likert. Menurut Sugiyono (2009) skala likert itu untuk mengukur sikap, pendapat dan persepsi seseorang atau sekelompok orang tentang fenomena sosial. Terdapat lima jawaban pada setiap pernyataan dengan skor 5 sampai 1 dengan kategori sangat setuju sampai sangat tidak setuju. Kuesioner di gunakan untuk mengumpulkan data mengenai persepsi wisatawan terhadap objek daya tarik wisata Tenganan Pegringsingan.

Kuesioner akan dilakukan uji validitas dan uji reliabilitas sebelum digunakan untuk mengumpulkan data. Dalam pengujian uji validitas dan reliabilitas menggunakan bantuan aplikasi Statistic Product and Service Solution (SPSS) for Windows versi 16.0. Penentuan valid atau tidak diperoleh dari perbandingan $r$-hitung dengan r-tabel dengan taraf signifikan 5\%. Instrumen dinyatakan valid apabila r-hitung $>$ r-tabel. Instrumen dinyatakan tidak valid apabila $r$ hitung < r-tabel. Sedangkan untuk mengetahui apakah variabel itu reliable dengan melihat nilai alpha cronbach $>0.60$. 
Teknik analisis dalam penelitian ini yaitu analisis data deskriptif. Pada Irianto (2004), tahapan analisis deskriptif yaitu (1) menentukan jumlah skor dari setiap dimensi dari data tabulasi yang merupakan hasil dari penyebaran kuesioner. (2) rentangan skor dengan skala Likert yaitu dari 1 sampai 5. (3) menentukan skor tertinggi dan skor terendah dari seluruh arternatif jawaban. Jumlah skor tertinggi $=$ skor tertinggi $\times$ jumlah pernyataan $\times$ jumlah responden. Jumlah skor terendah $=$ skor terendah $\times$ jumlah pertanyaan $\times$ jumlah responden. (4) menentukan rentang Interval, mempergunakan rumus.

Berikut perhitungan analisis deskriptif untzjk masing-masing dimensi.

$$
\text { Interval kelas }=\frac{\text { Range }}{c}
$$

Tabel 2. Perhitungan analisis desktiptif

\begin{tabular}{ccccc}
\hline Dimensi & Skor tertinggi & Skor terendah & Range skor & Interval Kelas \\
\hline Attractions & 6.500 & 1.300 & 5.200 & 1.040 \\
Amenities & 5.000 & 1.000 & 4.000 & 800 \\
Accessibility & 2.500 & 500 & 2.000 & 400 \\
\hline
\end{tabular}

Jadi berdasarkan perhitungan yang telah dipaparkan diatas memperoleh kriteria persepsi wisatawan terhadap objek daya tarik wisata Tenganan Pegringsingan, Kabupaten Karangasem adalah sebagai berikut.

Tabel 3. Kriteria dan rentang skor untuk dimensi attractions wisata

\begin{tabular}{lc}
\hline Rentang skor & Kategori \\
\hline $5.460-6.500$ & Sangat Setuju \\
$4.420-5.459$ & Setuju \\
$3.380-4.419$ & Cukup Setuju \\
$2.340-3.379$ & Tidak Setuju \\
$1.300-2.339$ & Sangat Tidak Setuju \\
\hline
\end{tabular}

Tabel 3. menunjukkan apabila persepsi wisatawan terhadap objek wisata Tenganan Pegringsingan ditinjau dari dimensi attractions masuk dalam rentang skor 5.460 - 6.500 mendapat kategori sangat setuju, rentang skor 4.420 - 5.459 masuk kategori setuju, rentang skor 3.380 - 4.419 masuk kategori cukup setuju, rentang skor $2.340-$ 3.379 masuk kategori tidak setuju dan apabila masuk dalam rentang skor $1.300-$ 2.339 memperoleh kategori sangat tidak setuju.

Tabel 4. Kriteria dan rentang skor untuk dimensi amenities wisata dapat ditentukan dengan formulasi sebagai berikut.

\begin{tabular}{lc}
\hline Rentang skor & Kategori \\
\hline $4.200-5.000$ & Sangat Setuju \\
$3.400-4.119$ & Setuju \\
$2.600-3.339$ & Cukup Setuju \\
$1.800-2.559$ & Tidak Setuju \\
$1.000-1.779$ & Sangat Tidak Setuju \\
\hline
\end{tabular}

Tabel 4. menunjukkan apabila persepsi wisatawan terhadap objek wisata Tenganan Pegringsingan ditinjau dari dimensi amenities masuk dalam rentang skor 4.200 - 5.000 mendapat kategori sangat setuju, rentang skor 3.400 - 4.119 masuk kategori setuju, rentang skor 2.600 - 3.339 masuk kategori cukup setuju, rentang skor $1.800-$ 2.559 masuk kategori tidak setuju dan apabila masuk dalam rentang skor 1.000 1.779 memperoleh kategori sangat tidak setuju. 
Tabel 5. Kriteria dan rentang skor untuk dimensi accessibility wisata dapat ditentukan dengan formulasi sebagai berikut.

\begin{tabular}{cc}
\hline Rentang skor & Kategori \\
\hline $1.200-2.500$ & Sangat Setuju \\
$1.700-2.099$ & Setuju \\
$1.300-1.699$ & Cukup Setuju \\
$900-1.299$ & Tidak Setuju \\
$500-899$ & Sangat Tidak Setuju \\
\hline
\end{tabular}

Tabel 5. menunjukkan apabila persepsi wisatawan terhadap objek wisata Tenganan Pegringsingan ditinjau dari dimensi accessibility, masuk dalam rentang skor $1.200-2.500$ mendapat kategori sangat setuju, rentang skor $1.700-2.099$ masuk kategori setuju, rentang skor $1.300-1.699$ masuk kategori cukup setuju, rentang skor 900 - 1.299 masuk kategori tidak setuju dan apabila masuk dalam rentang skor 900
- 899 memperoleh kategori sangat tidak setuju.

\section{HASIL DAN PEMBAHASAN \\ Hasil Penelitian}

Berdasarkan perhitungan analisis data yang dilakukan, maka persepsi wisatawan terhadap objek daya tarik wisata Tenganan Pegringsingan ditinjau dari dimensi attractions, amenities dan accessibility hasilnya dapat dilihat pada tabel sebagai berikut.

Tabel 6. Hasil penelitian persepsi wisatawan terhadap objek daya tarik wisata tenganan pegringsingan ditinjau dari dimensi attractions

\begin{tabular}{lllccc}
\hline Dimensi & \multicolumn{1}{c}{ Indikator } & Skor & Range Skor & Kategori \\
\hline \multirow{5}{*}{ Attractions } & 1. & Keunikan dan keindahan alam & 1.374 & $1.260-1.500$ & Sangat Setuju \\
& 2. & Kemenarikan tradisi dan budaya & 912 & $680-839$ & Sangat Setuju \\
& 3. Kemenarikan jalur tracking & 1.260 & $1.260-1.500$ & Sangat Setuju \\
& 4. Masyarakat setempat & 1.300 & $1.260-1.500$ & Sangat Setuju \\
& 5. Keamanan objek wisata & 847 & $840-1.000$ & Sangat Setuju \\
\hline & Total & 5.693 & $5.469-6.500$ & Sangat Setuju \\
\hline
\end{tabular}

Hasil penelitian tersebut menunjukkan bahwa persepsi wisatawan terhadap objek daya tarik wisata Tenganan Pegringsingan yang ditinjau dari dimensi attractions pada indikator keunikan dan keindahan alam memiliki skor 1.374 masuk dalam range skor 1.260 - 1.500 dengan kriteria sangat setuju. Pada indikator kemenarikan tradisi dan budaya memiliki skor 912 masuk dalam range skor 840 1.000 dengan kriteria sangat setuju. Untuk indikator kemenarikan jalur tracking memiliki skor 1.260 masuk range skor $1.260-1.500$ dengan kriteria sangat setuju. Indikator masyarakat setempat memiliki skor 1.300 masuk range skor 1.260 - 1.500 dengan kriteria sangat setuju. Untuk indikator keamanan objek wisata memiliki skor 847 masuk dalam range skor $840-1.000$ dengan kriteria sangat setuju. Secara keseluruhan persepsi wisatawan terhadap objek daya tarik wisata Tenganan Pegringsingan yang ditinjau dari dimensi attractions memiliki skor total 5.693 masuk dalam range skor $5.469-6.500$ dengan kriteria sangat setuju.

Tabel 7. Hasil penelitian persepsi wisatawan terhadap objek daya tarik wisata tenganan pegringsingan ditinjau dari dimensi amenities

\begin{tabular}{|c|c|c|c|c|}
\hline Dimensi & Indikator & Skor & Range Skor & Kategori \\
\hline \multirow[b]{2}{*}{ Amenities } & $\begin{array}{l}\text { 1. Ketersediaan sarana akomodasi pada } \\
\text { objek wisata }\end{array}$ & 1.690 & $1.680-2000$ & Sangat setuju \\
\hline & $\begin{array}{l}\text { 2. Ketersediaan sarana pendukung pada } \\
\text { objek wisata }\end{array}$ & 2.578 & $2.520-3.000$ & Sangat setuju \\
\hline \multicolumn{2}{|l|}{ Total } & 4.268 & $4.200-5.000$ & Sangat setuju \\
\hline \multicolumn{2}{|c|}{ Apabila ditinjau dari dimensi amenities } & \multicolumn{3}{|c|}{ komodasi pada objek wisata memiliki sk } \\
\hline
\end{tabular}


dengan kriteria sangat setuju. Pada indikator ketersediaan sarana pendukung pada objek wisata memiliki skor 2.578 masuk range skor 2.520 - 3.000 dengan kriteria sangat setuju. Secara keseluruhan persepsi wisatawan terhadap objek daya tarik wisata Tenganan Pegringsingan yang ditinjau dari dimensi amenities memiliki skor 4.268 masuk range skor $4.200-5.000$ masuk kriteria sangat setuju.

Tabel 8. Hasil penelitian persepsi wisatawan terhadap objek daya tarik wisata Tenganan Pegringsingan ditinjau dari dimensi accessibility

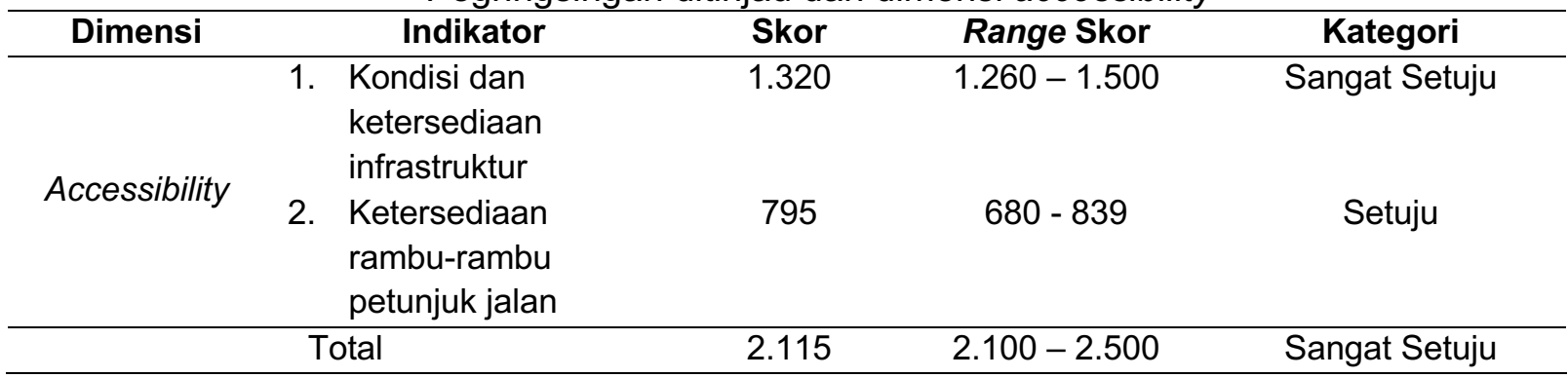

Apabila ditinjau dari dimensi accessibility pada indikator kondisi dan ketersediaan infrastruktur mendapat skor 1.320 masuk dalam range skor 1.260 1.500 dengan kriteria sangat setuju. Pada indikator ketersediaan rambu-rambu petunjuk jalan mendapat skor 795 masuk dalam range skor 680 - 839 dengan kriteria setuju. Secara keseluruhan persepsi wisatawan terhadap objek daya tarik wisata Tenganan Pegringsingan yang ditinjau dari dimensi accessibility memiliki skor 2.115 masuk dalam range skor $2.100-2.500$ dengan kriteria sangat setuju.

\section{Pembahasan}

Berdasarkan hasil penelitian persepsi wisatawan terhadap objek daya tarik wisata Tenganan Pegringsingan yang ditinjau dari dimensi attraction, amenities dan accessibility mendapatkan persepsi sangat setuju dari wisatawan. Hal ini berarti objek wisata Tenganan Pegringsingan, Kabupaten karangasem sudah dapat menyediakan komponen penting pariwisata yaitu attractions, amenities dan accessibility seperti yang diungkapkan oleh (Holloway, dkk, 2009). Pada suatu objek wisata wajib dalam memenuhi komponen utama pariwisata yaitu tersedianya hal yang menarik pada objek wisata. Ketersediaan beragam atraksi wisata dapat menjadi motivasi penting dalam mendorong kehadiran wisatawan. Atraksi (attractions) objek wisata berkaitan dengan segala hal yang dapat dilihat dan segala hal yang dapat dilakukan oleh wisatawan. Pada objek daya tarik wisata Tenganan Pegringsingan yang menjadi daya tarik utama bagi wisatawan adalah tradisi, kebudayaan dan tracking. Pelaksanaan tradisi dapat disaksikan secara langsung oleh wisatawan. Selain itu tradisi tersebut hanya dapat ditemukan pada objek daya tarik wisata Tenganan Pegringsingan, hal tersebut yang membuat objek wisata ini berbeda dari objek dan desa wisata yang lainnya. Hasil penelitian ini sejalan dengan Maryani (dalam Utama, 2017) yang menunjukkan pada objek wisata harus memiliki atraksi (segala hal yang dapat disaksikan) yang dapat dijadikan sebagai hiburan bagi wisatawan. Selain kondisi alam dan hiburan yang dapat disaksikan, wisatawan akan merasa senang, nyaman dan merasa dianggap oleh masyarakat setempat apabila suatu objek wisata apabila diimbangi keramaha-tamahan masyarakat sekitar objek wisata dan lingkungan objek wisata yang sangat aman untuk dikunjungi wisatawan. Hasil penelitian ini juga sejalan dengan penelitian Keliwar \& Nurcahyo (2015) yang menyatakan segala hal yang menarik pada sebuah objek wisata menjadi faktor yang melatarbelakangi keputusan wisatawan untuk berkunjung pada objek wisata.

Wisatawan dalam memutuskan melakukan kunjungan wisata sangat memperhatikan fasilitas-fasilitas yang ada pada objek wisata. Fasilitas berkaitan dengan segala hal yang menimbulkan rasa 
nyaman bagi wisatawan selama berada pada suatu tempat wisata. Adanya amenities wisata berguna untuk memenuhi segala hal yang dibutuhkan oleh wisatawan. Hasil ini sejalan dengan penelitian yang dilakukan oleh Abdulhaji \& Yusuf (2016) yang menyatakan apabila suatu objek wisata menyediakan fasilitas wisata yang menjadi kebutuhan pengunjung maka akan mendorong calon wisatawan untuk berkunjung dan menikmati suatu objek wisata yang relatif lama. Ketersediaan warung makan dan minum, toko cinderamata/ souvenir pada objek dan tiket masuk untuk wisatawan dapat menikmati objek wisata yang dikunjungi. Toko cinderamata yang dijual merupakan hasil buatan sendiri masyarakat Tenganan Pegringsingan. Hal yang menjadi daya tarik tersendiri yaitu cara menjual hasil kerajinan dan karya seninya dan tempat atau toko penjual souvenir.

Selain itu ketersediaan sarana pendukung objek wisata juga dapat dilengkapi mulai dari adanya galeri foto, adanya toilet yang bersih, adanya tempat parkir untuk kendaraan wisatawan, adanya tempat istirahat/ rest area/ gazebo untuk wisatawan, adanya tempat sampah dan tersedianya informasi tentang objek wisata Tenganan Pegringsingan pada internet dan media sosial. Sarana pendukung yang ada pada objek wisata Tenganan Pegringsingan dapat dikatakan lengkap. Amenities yang lengkap dan berkualitas dapat membuat wisatawan merasa nyaman sehingga menimbulkan rasa senang selama berkunjung ke suatu daerah tujuan wisata. Hasil peneltian didukung oleh pendapat maryani (dalam Utama, 2017) tempat wisata harus dapat menyediakan beberapa fasilitas penunjang untuk belanja terutama barang souvenir dan kerajinan yang dapat digunakan sebagai oleh-oleh bagi wisatawan.

Komponen terakhir yang perlu disediakan adalah accessibility. Accessibility merupakan kemudahan wisatawan untuk menjangkau objek wisata yang akan dikunjungi. Pada objek wisata Tenganan Pegringsingan dapat menyediakan akses jalan yang mudah, kualitas jalan dalam kondisi baik dan tidak ada hambatan lalu lintas ketika wisatawan akan melakukan kunjungan ke objek daya tarik wisata Tenganan Pegringsingan. Selain itu ketika wisatawan ingin berkunjung ke objek daya tarik wisata Tenganan Pegringsingan, papan petunjuk jalan akan berguna sebagai petunjuk wisatawan agar dapat mencapai suatu objek wisata. Wisatawan akan tertarik oleh akses jalan yang baik. Semakin mudah aksesibilitas suatu daerah tujuan wisata dijangkau oleh wisatawan maka dapat meningkatkan kunjungan wisatawan. Hasil penelitian ini sejalan dengan Holloway, dkk (2009) yang menyatakan adanya akses yang mudah untuk menuju suatu objek wisata dapat menarik wisatawan dalam melakukan perjalanan wisata dan bagi sebagian wisatawan tidak akan tertarik apabila suatu daerah wisata tersebut sulit untuk dijangkau. Hasil penelitian ini juga sejalan dengan penelitian yang dilakukan oleh Abdulhaji \& Yusuf (2016) yang menyatakan tercapainya suatu objek wisata merupakan akhir perjalanan sehingga perlu untuk memenuhi aspek aksessibilitas yang artinya suatu objek wisata harus mudah dicapai dan mudah ditemukan oleh wisatawan.

Berdasarkan pembahasan diatas dapat disimpulkan bahwa objek daya tarik wisata Tenganan Pegringsingan memiliki daya tarik dilihat dari dimensi attractions, amenities dan accessibility. Penelitian ini sejalan dengan Holloway, dkk (2009) yang menyatakan, keberhasilan dalam menarik wisatawan ke suatu objek wisata tergantung kepada komponen-komponen penting yang ditawarkan objek wisata kepada wisatawan yang terdiri dari attractions, amenities dan accessibility. Pada objek wisata Tenganan Pegringsingan sudah dapat menyediakan komponen penting pariwisata yaitu attractions, amenities dan accessibility. Hasil Penelitian ini menunjukkan bahwa persepsi wisatawan terhadap objek daya tarik wisata Tenganan Pegringsingan untuk dimensi attractions, amenities dan accessibility mendapatkan persepsi yang positif dari wisatawan.

\section{SIMPULAN DAN SARAN \\ Simpulan}

Persepsi wisatawan terhadap objek daya tarik wisata Tenganan Pegringsingan yang ditinjau dari dimensi attractions 
memiliki skor total 5.693 masuk dalam range skor 5.469 - 6.500 dengan kriteria sangat setuju. Hal tersebut menunjukkan bahwa objek wisata Tenganan Pengringsingan memiliki keunikan dan keindahan alam yang sangat unik dan indah, memiliki tradisi dan budaya yang sangat menarik dan hanya ada pada objek wisata tersebut, adanya wisata tracking yang memiliki jalur yang mudah dan menarik, masyarakat sekitar objek sangat menerima kedatangan wisatawan sehingga tercipta kenyamanan wisatawan dalam berkunjung (adanya keramah-tamahan masyarakat) dan lingkungan objek wisata yang aman.

Persepsi wisatawan terhadap objek daya tarik wisata tenganan pegringsingan ditinjau dari dimensi amenities memiliki skor 4.268 masuk range skor $4.200-5.000$ masuk kriteria sangat setuju. Hal tersebut menunjukkan bahwa pada objek wisata Tenganan Pegringsingan terdapat warung makan dan minum, terdapat toko cinderamata (art shop) yang unik, menyediakan sistem donasi kepada wisatawan yang akan menyumbang secara sukarela dan terdapat sarana pendukung berupa adanya galeri foto, tempat parkir, toilet, rest area, tempat sampah dan adanya informasi mengenai objek wisata Tenganan Pegringsingan pada internet atau media sosial.

Persepsi wisatawan terhadap objek daya tarik wisata Tenganan Pegringsingan yang ditinjau dari dimensi accessibility memiliki skor 2.115 masuk dalam range skor $2.100-2.500$ dengan kriteria sangat setuju. Hal tersebut menunjukkan bahwa objek wisata Tenganan Pegringsingan memiliki kemudahan dalam mencapai objek wisata, kualitas jalan yang baik dan tidak ada hambatan lalu lintas. Dan tersedia rambu-rambu petunjuk jalan yang dapat menunjukkan lokasi objek wisata Tenganan Pegringsingan.

\section{Saran}

Saran yang dapat disampaikan penulis kepada pengelola objek daya tarik wisata Tenganan Pegringsingan yaitu agar diperhatikan kondisi fasilitas wisata, menjaga fasilitas wisata yang sudah ada agar dalam kondisi yang baik ketika digunakan oleh wisatawan dan menjaga kebersihan lingkungan objek wisata. Semakin baik suatu objek wisata bagi wisatawan, maka objek wisata yang dikunjungi wisatawan akan mendapatkan persepsi yang positif. Persepsi positif pada objek wisata dapat mengembangkan dan menarik wisatawan untuk mengunjungi objek wisata tersebut.

Untuk peneliti selanjutnya yang tertarik untuk mengkaji aspek serupa mengenai persepsi wisatawan terhadap objek wisata, diharapkan untuk mengembangkan penelitian ini dengan menggunakan instrumen penelitian yang lebih luas, memperluas penggunaan sampel dan diharapkan dapat menganalisis, menambahkan faktor-faktor lain yang menjadi daya tarik wisatawan untuk berkunjung ke objek daya tarik wisata Tenganan Pegringsingan dan objek wisata lainnya.

\section{DAFTAR PUSTAKA}

Abdulhaji, S. \& I. S. H. Y. (2016). Pengaruh Atraksi, Aksesibilitas, dan Fasilitas Terhadap Citra Objek Wisata Danau Tolire Besar di Kota Ternate. Jurnal Penelitian Humano, 7 (2): 134-148.

Abdullah, T. (2017). Penilaian Wisatawan akan Atribut Pariwisata di Kota Batu. THE Journal : Tourism and Hospitality Essentials Journal, 7 (2): 1-18. https://doi.org/10.17509/thej.v7i2.9015

Anggela, M. M., Karini, N. M. O , \& Wijaya, N. M. S. 2017. Persepsi dan Motivasi Wisatawan yang Berkunjung ke Daya Tarik Wisata Jembong Di Kabupaten Buleleng. Jurnal IPTA, 5(2): 76-91 https://doi.org/10.24843/ipta.2017.v05 .i02.p01

Anggraeni, D. (2013). Persepsi Wisatawan terhadap Variasi Objek Wisata di Pantai Glagah Kulonprogo. Bumi Indonesia, 2 (4): 1- 8

Desa Tenganan. (2019). Data Kunjungan Wisatawan Objek Wisata Tenganan. Tenganan, Manggis, Karangasem.

Devy, H. A. (2017). Pengembangan Obyek dan Daya Tarik Wisata Alam Sebagai Daerah Tujuan Wisata di Kabupaten Karanganyar. Jurnal Sosiologi DILEMA, 32(1): 34-44. 
Fajri, K., \& Riyanto E.S, N. (2016). Strategi Pengembangan Destinasi Pariwisata Kota Bandung dalam Meningkatkan Tingkat Kunjungan Wisatawan Asal Malaysia. Tourism Scientific Journal, 1 (2): 167-183. https://doi.org/10.32659/tsj.v1i2.9

Fentri, D. M. (2017). Persepsi Pengunjung terhadap Daya Tarik Taman Wisata Alam Hutan Rimbo Tujuh Danau di Desa Wisata Buluh Cina Kecamatan Siak Hulu Kabupaten Kampar Riau. Jom Fisip, 4 (2): 1-11.

Holloway, J. Cristopher, Humphreys, Claire dan Davidson, R. (2009). The Business of Tourism (8th Edition). ENGLAND: Pearson Education Limited.

Irianto, A. (2004). Statistik Konsep Dasar dan Aplikasinya. Jakarta: PT. Bumi Aksara.

Keliwar, S., \& Nurcahyo, A. (2015). Jurnal Manajemen Resort dan Leisure Vol. 12, No. 2, Oktober 2015 Motivasi Dan Persepsi Pengunjung terhadap Obyek Wisata Desa Budaya Pampang di Samarinda. Jurnal Manajemen Resort, 12 (2): 10-27.

Nisa, K., Fauzi, H., \& Abrani. (2014). Persepsi Wisata dan Masyarakat Terhadap Wisata Alam di Areal Hutan Pendidikan UNLAM MANDIANGIN, Kalimantan Selatan. Jurnal Hutan Tropis, 2 (2): 119-126

Noor, J. (2011). Metodologi Penelitian: Skripsi, Tesis, Disertasi, dan Karya IImiah. (Edisi Pert). Jakarta: Kencana Prenada media Group.

Nugroho, F. G. (2016). Faktor-faktor yang Mempengaruhi Menurunnya Jumlah Pengunjung di Obyek Wisata Air Bojongsari (Owabong). 5 (4): 366379.

Utama, I. G. B. R. (2017). Pemasaran Pariwisata. Yogyakarta: ANDI.

Rakhmat, J. (2013). Psikologi Komunikasi. Edisi Revisi. Bandung: Remaja Rosdakarya.

Sayangbatti, D. P. (2013). Motivasi dan Persepsi Wisatawan Tentang Daya Tarik Destinasi Terhadap Minat Kunjungan Kembali di Kota Wisata Batu. 5 (2): 126-136. https://doi.org/10.22146/jnp.6372

Suarnayasa, K., \& Haris, I. A. (2019). Persepsi Wisatawan terhadap Keberadaan Objek Wisata Air Terjun di Dusun Jembong. Jurnal Pendidikan Ekonomi Undiksha, 9 (2): 473-483. https://doi.org/10.23887/jjpe.v9i2.2013 2

Sugiyono. (2009). Metode Penelitian Kuantitatif, Kualitatif dan R\&D. Bandung: Alfabeta.

Suwena, I Ketut \& Widyatama, I. G. N. (2017). Pengetahuan Dasar IImu Pariwisata. Denpasar: Pustaka Larasan.

Wardiyanta. (2010). Metode Penelitian Pariwisata (Edisi 2). Yogyakarta: ANDI.

Wilopo, Khusnul Khotimah \& Hakim, L. (2017). Strategi Pengembangan Destinasi Pariwisata Budaya (Studi Kasus pada Kawasan Situs Trowulan sebagai Pariwisata Budaya Unggulan di Kabupaten Mojokerto). Jurnal Administrasi Bisnis S1 Universitas Brawijaya, 42 (1): 56-65.

Witarsana, I. K. (2017). Motivasi dan Persepsi Wisatawan Mancanegara Berwisata Alam Trekking Mountain Di Taman Wisata Alam Gunung Batur Bukit Payang. 5 (1): 13-19. 